\title{
Uusioersily
}

\section{Reconciliation and After in Northern Ireland: The Search for a Political Order in an Ethnically Divided Society}

Morrow, D. (2017). Reconciliation and After in Northern Ireland: The Search for a Political Order in an Ethnically Divided Society. Nationalism and Ethnic Politics, 23(1), 98-117. https://doi.org/10.1080/13537113.2017.1273688

Link to publication record in Ulster University Research Portal

\section{Published in:}

Nationalism and Ethnic Politics

Publication Status:

Published online: 20/01/2017

DOI:

10.1080/13537113.2017.1273688

\section{Document Version}

Author Accepted version

\section{General rights}

Copyright for the publications made accessible via Ulster University's Research Portal is retained by the author(s) and / or other copyright owners and it is a condition of accessing these publications that users recognise and abide by the legal requirements associated with these rights.

\section{Take down policy}

The Research Portal is Ulster University's institutional repository that provides access to Ulster's research outputs. Every effort has been made to ensure that content in the Research Portal does not infringe any person's rights, or applicable UK laws. If you discover content in the Research Portal that you believe breaches copyright or violates any law, please contact pure-support@ulster.ac.uk. 


\title{
Reconciliation and After in Northern Ireland: The search for a Political Order in an Ethnically Divided Society
}

\author{
DUNCAN MORROW \\ Ulster University
}

\begin{abstract}
Since Westphalia, territoriality has been a critical element in the political management of violence. Where legitimacy was contested, as in the area that became Northern Ireland, territorial disputes often escalated into significant violence. The importance to human futures of controlling violence is the central theme of the work of Rene Girard. This article explores the implications of Girardian thinking for understanding both the escalation of violence in Northern Ireland after the 1960s, and efforts to escape the dictates of territoriality in the peace which followed. In particular, it explores the concept of reconciliation and its application amidst endemic political rivalry.
\end{abstract}

\section{TERRITORY, LEGITIMACY AND VIOLENCE AFTER EMPIRE}

Since 1648, the territorial principle has been the lynchpin of the Western political system. As Max Weber observed, state territorial sovereignty was identical with control of the monopoly of legitimate violence ${ }^{1}$. Modern political order and law was built on the transcendent power of the state alone to distinguish good violence, or force, from bad violence, or crime within its territorial limits.

In practice this monopoly was always limited. Until 1914, European states, and their settler colonies, pursued empire by distinguishing 'internal frontiers' between the central metropolitan core and the imperial extension. Outside the metropolis, the distinction between law and violence was asserted by what Carl Schmitt called the 'state of exception', eliding the legal with the non-legal and treating decisions which would have been illegal at home as having the force of law outside the metropolitan core ${ }^{2}$. As Hannah Arendt observed, the boundary between force and violence evaporated in the imperial space into lawlessness ${ }^{3}$.

In Britain and France, the distinction between the core and the empire was given physical expression in the concept of 'overseas', translating an exercise in extended power into a mission to civilise, encapsulated as the burden of the white man "to wait in heavy harness on fluttered folk and wild, - your new-caught sullen peoples, half devil and half child." 4

But in the land empires of Europe, the distinction was less clear-cut. In large parts of the Austro-Hungarian and Ottoman Empires, as well as the margins of Russia and Germany populations met and 'bled into' each other. As literacy and economic transformation spread, central authority began to face organised counter-claims by democratic 'nations' to legitimacy. The difference between force and violence and the boundaries between internal and external were increasingly contested. 
The decaying Ottoman Empire in the Balkans was the cradle of crisis. But the watershed for imperial legitimacy was World War I. The brutality of imperial war radically undermined the legitimacy of the regimes which prosecuted it but lost. In 1918, Woodrow Wilson confirmed the legitimacy of anti-imperialism among the 'subject' peoples of the defeated empires when he made national self-determination the central pillar of a just post-War peace:

"What we demand in this war, therefore, is nothing peculiar to ourselves. It is that the world be made fit and safe to live in; and particularly that it be made safe for every peace-loving nation which, like our own, wishes to live its own life, determine its own institutions, be assured of justice and fair dealing by the other peoples of the world as against force and selfish aggression." 5

But in declaring that free sovereignty over territory was equivalent to national self- assertion, Wilson inevitably transformed territories previously contained within single dynastic territories across Central and Eastern Europe into objects of bitterly contested claims by 'national selves'. The claims drew variously on a convenient mix of historic claims, modern demographic majorities or physical contiguity. Territories where sovereignty, and hence the monopoly of legitimate violence, was claimed by more than one nation were transformed into 'interfaces' between rival claims, described by Frank Wright as 'ethnic frontiers'. Was Bohemia a historic indivisible unity, or must it be divided into separate constituent parts by language majorities? Was Slovakia a definable territory at all? And what of the $2.8 \mathrm{~m}$ Jews spread across the new Poland?

The Allies in 1918 found that picking national winners automatically implied national losers in many post-imperial territories. By definition, these decisions determined the distinction between legitimate and illegitimate violence. In general, the victors resolved dilemmas against the defeated Central powers while exempting themselves from the principle altogether ${ }^{6}$. The Peace Treaties left the Russians untouched and crushed the ambitions of 'lesser winners' in Japan and Italy. Within twenty years, democracy had been replaced by one-party authoritarianisms in Germany, Italy, Russia and Japan claiming authority outside their allotted territory, and rejecting the decisions taken about legitimate violence at Versailles.

\section{THE CRISIS OF NATIONALITY IN IRELAND}

Formally, the British Empire, victorious and still expanding in 1918, was unaffected by post-War peace talks. But for forty years prior to the War, the same issues made Ireland the intractable centre of constitutional politics in the United Kingdom. In practice, the contest of post-imperial legitimacy that engulfed the postwar World could not be contained to 'other people's' territories.

Long before 1914, Ireland had occupied a unique place in the British Empire. While Ireland was in theory core to the unitary imperial state, participating directly in Victorian democratic reforms, Irish politics were marked by what Frank Wright describes as a "crisis of assimilation.' ${ }^{7}$ As literacy and democracy spread, Ireland voted and agitated distinctively in relation to the imperial centre and to the law. 
Faced with a resistant 'internal-other', Gladstone, the dominant Liberal politician of his age, came to the conviction that only Irish self-government in domestic matters could preserve the longer-term unity of the United Kingdom and introduced his first 'Home Rule' Bill in 1885. But Gladstone's conversion surfaced powerful subterranean conflicts about legitimacy, the British 'national' interest and identity, which ultimately broke both the Liberal Party and the consensus of the British ruling class. It also broke Ireland.

As the transcendence of the imperial state failed in Ireland, it failed unevenly. The territorial locus for this 'crisis within a crisis' was in the north of Ireland. Whereas Gladstone and Irish nationalists treated Ireland as a single defined territorial jurisdiction, they underplayed the distinct legacy of Empire and industrialisation in the northeast. Here, the crisis of assimilation after 1885 revitalised the persistent indigenous political conflict between British state loyalists (Unionists) and Irish nationalists, defined still by religious affiliation.

By relocating the locus of territorial sovereignty from the Empire to popular national identity, Home Rule almost instantly crystallised political alignments, modernised the association between imperialism and religious identity and dynamically accelerated polarisation. Proposals to hand power to nationalist Ireland placed the British state in direct opposition to its own most fervently loyal 'citizens' on the island, a zeal that opponents of Home Rule were determined to harness. In practice this meant encouraging the determination of Unionists to resist 'betrayal' especially in Ulster where they were economically and territorially dominant. By raising the potential for confrontation between the state and its most fervent loyalists (through what Frank Wright calls 'deterrence actions' $)^{8}$ the Home Rule question triggered a wider sense of imperial crisis.

When Home Rule became a realistic prospect after 1911, the Unionists raised their cause into an explicitly sacred enterprise, mobilised a large popular militia and threatened armed insurrection. "Humbly relying on God", almost half a million Unionists pledged to use "all means which may be found necessary to defeat the present conspiracy to set up a Home Rule Parliament in Ireland." "For this they received both explicit parliamentary cover from the Conservative opposition, including thinly-veiled support for righteous violent resistance. By the time of the outbreak of World War I, an escalation to new extremes was underway.

The decisive final straw was the War itself which radicalised nationalism and uprooted the established order everywhere. In the slaughter of the Somme and the heroic failure of the Easter Rising, each side in Ireland had their sacred martyrs and glorious dead. The moderate pro-devolution Irish Parliamentary Party had been eclipsed by the revolutionary pro-Independence politics of Sinn Fein across much of Ireland and in Protestant Ulster, Unionism's wartime loyalty to the imperial cause had reinforced their determination to resist separation from the imperial mother-ship. A pre-War constitutional crisis had escalated into violent confrontation characterised by insurgent terrorism and harsh counter-insurgency. But as part of the victorious British Empire, there was never any prospect that Ireland would be considered at the Paris Peace Conference.

The British government resolved its immediate legitimacy crisis through conceding to the dual logic of 'territorial larger forces' and proposed not one, but two, 
Home Rule parliaments in Northern and Southern Ireland, both within the United Kingdom. This had the clear advantage of not requiring the British state to confront either party in Ireland by creating a clear Unionist majority in the North and an overwhelming Nationalist majority in the South. Although it met no organised prior demand, the idea of 'Northern Ireland' was a desperate pragmatic attempt at managing the increasingly unmanageable, a technocratic constitutional device to bring some administratively enforceable calm in a context of irreconcilable rivals. Its appeal to London was not so much its desirability as its feasibility.

Ironically, Home Rule in this version suited the imperial loyalists but incensed radical Irish Nationalism. But while Nationalists could veto devolution in the South, they had no capacity to prevent the establishment of British-backed Unionist domination in the North. When the British conceded greater independence to Ireland only months later, 'Northern Ireland' opted out.

\section{VIOLENCE AND TRANSCENDENT ORDER}

Wilson intended democracy to free nations from the shackles of imperial domination. Within 20 years East-Central Europe descended into a catastrophe of national rivalry. Under the cloak of self-determination ('Heim ins Reich') and challenging the humiliation of the 'Versailles traitors', Hitler marched into the Saarland, Austria and Czechoslovakia. In his obsession to avenge German humiliation at Versailles, selfdetermination became lebensraum and then the final solution. Sacred authority was claimed for unspeakable violence in the service of nation. Previously inconceivable ethnic violence, in what Timothy Snyder has called 'the Bloodlands', engulfed the resented 'national' states between Germany and Russia. ${ }^{10}$

Violence and the sacred is core to the work of Rene Girard ${ }^{11}$. Girard roots human violence in competing and escalating desires for the same object. The objects of desire do not emerge spontaneously but from emulation, or 'mimesis' of the desires of others. Human existence is mimetic rather than autonomous, interdependent rather than independent. But because human desire is imitative or 'mimetic', it has the tendency to polarise around desire for the same object.

The mimetic qualities of desire mean that the escalating resistance increases fascination. At an unpredictable point, rivalry over an object or possession escalates into direct rivalry with the rival preventing possession, and towards violence.

The escalation to mimetic violence is the greatest threat to human survival. Establishing the social order is therefore crucial. Unlike Hobbes, Girard rejects the notion of rational 'social contract' as the origin of order in a mimetic frenzy. 'Peace' requires a change the mimetic relationships in the community. Girard hypothesises that human culture, including the social and religious order, arose from the limitation of violence which could only emerge when violence mimetically converged on a single designated 'other'. Social peace is the consequence of the violence of 'all against one'. The rivalry of the community is driven out with its scapegoat.

Crucially, the process, and the violent participation of the mob, remains hidden from its beneficiaries. The miraculous, if paradoxical, peace among the remaining 
community results from externalising violence. From within, peace is attributed as the objective action of the scapegoat. Religion and culture recount their origins as 'myth': the experience of scapegoating as recounted by its beneficiaries ${ }^{12}$. For Girard, the sacred is revealed as the violence which drove out the scapegoat, a violence which is threatened if the sacred order is transgressed. The community has its peace from internal violence by attributing it 'externally', to a divine 'other'.

The central function of religion and culture is the regulation of internal mimetic violence through prohibitions and taboos and structures and ritual. When cultural order is threatened, cultures and religions intuitively seek peace by directing sacred violence (disguised as force) against an external other. Culture therefore 'contains' violence in both senses of contain: rooted in violence, it contains wider violence.

Modernity stands in a complex relationship to this process. On the one hand, the state is the inheritor of sacred authority as the holder of the monopoly of legitimate violence. On the other, the modern western state stands at the end of a long gradual process during which the origin of the sacred in violence has gradually emerged. Girard attributes the demystification of violence to the extending influence of JudaeoChristianity, and in particular to the reversal of the scapegoat mechanism in the crucifixion ${ }^{13}$. Violence along with the complicity of the mob is revealed and its sacred claims destroyed. At the same time, Judaeo-Christianity strips modernity of the protection of sacred violence against mimetic escalation. Violence exercised in the name of the sacred is increasingly 'just violence' and without limitation.

Modernity exhibits an unparalleled sensitivity for victims and to the complicity of social order with violence, including its own. But it has also disarms the sacred transcendence under which the state managed illegitimate violence with legitimate force. Where the force of the state is declared illegitimate, the ability of the state to mediate violence and establish order disappears. Where legitimacy is claimed for a rival violence, the potential for mimetic escalation is limited only by the balance of forces. Even in the case where the enemy is destroyed, violence achieves no cultural closure. Violence can no longer be hidden. Instead of driving out violence, violence rebounds on its users and generates imitators.

When Woodrow Wilson declared the transcendence of democracy exercised as national self-determination in 1918, many territories became subject to rival claims to a monopoly of violence where the only 'control' was the balance of forces. When the borders of legitimacy were actually determined by victors who continued to assert imperial legitimacy in their own territories, they also incensed the truncated and frustrated empires. The distance between a declaration that national self-determination is sovereign and an insistence that violence in service of the nation is legitimate or even obligatory where self-determination is challenged proved to be very short. Everywhere, violence was justified as force in the service of legitimate ends. But the only consistent distinction between force and violence was subjective: 'our' violence is force, and 'their' violence criminal. Violence no longer drove out violence, but escalated it. As Paul Dumouchel observes, "like sacrifice, political violence is a form of violence designed to protect against violence... it is now unable to protect us from violence or give rise to a stable order." 14 


\section{RIVALRY AND ORDER IN THE ETHNIC FRONTIER}

'Empire loyalists' in ethnically contested areas of Austria-Hungary and Germany found themselves minorities in new national challenger-states where territory was contested. The lost territories in the East were transformed into evidence of the humiliation of the German nation at Versailles. As Paul Dumouchel observes: "we no longer have the territorial order, a continuous isotropic space of which each part is external to each other..."15.

Escalated international territorial rivalry had direct consequences for the internal politics of the new states. Where there was an unredeemed minority now under foreign authority, domestic policy was aligned to foreign policy. Where an internal 'other' emerged, politics relied on vigilance. Where one part of its (internal) population was regarded as an (external) threat, the law became part of the process of pre-emption and escalation. Rivalry over sovereignty was reflected in systemic inequality, deepening resentment. The exercise by the state of its monopoly of legitimate force resembled the opposition it confronted, eroding, and eventually eliminating, the distinction between force and violence on which the law relies for its monopoly.

Wright characterizes the resulting relationship as endemic 'antagonism', defined as 'being on different sides of a force [and violence] relationship'. The path of conflict in the ethnic frontier is measured less by the possession of specific objects than by ensuring advantage in the mimetic rivalry itself. Politics is about relativities rather than absolutes change. As Frank Wright points out 'Antagonism (mimetic rivalry) is more fundamental than all the various 'things' the antagonism keeps for the dominant and denies to the dominated." 16 Potentially anything which threatens the balance of power, can trigger hostility. Crucially, conflict cannot be 'resolved' simply by establishing frameworks of formal equality around 'things' for as long as the mimetic suspicion remains intact.

Political relationships in a force field are simultaneously characterised by hostility between rivals and internal group solidarity. Violence, or the threat of violence, is simultaneously fascinating and polarising (alienating). Group identity becomes critical as violence becomes 'representative'. An attack on one member of a group is experienced as an attack on the whole group, while all members of 'the others' are implicitly complicit in any violence. Vengeance can potentially be taken against any identified member. Relationships between individuals are increasingly conducted within the wider mimetic antagonism. Ultimately groups have their collective identity vis-a-vis an ideologically singular 'them', which is simultaneously everywhere. Directing violence in the name of vigilance, deterrence and suspicion become the highest virtues of patriotism.

Technical categories such as 'citizenship' must be parsed in practice into friends and foes, institutionalising suspicion and inequality at the heart of all processes of state. Equality is rendered implausible by the need to have a pre-emptive advantage over a rival terror. Peace without victory is tantamount to surrender, equivalent to trusting a Trojan horse. Even an 'absence of violence' in which the relationship of antagonism remains untouched is experienced as a truce.

Wright demonstrates that the crucial differences between Eastern Europe and Ireland lay in the external environment. The crisis of rival claims to self-determination was resolved by creating Northern Ireland inside the old imperial state. By determining 
its own process of exit from Empire, Britain avoided the humiliation of international dictation. By upholding the position of empire loyalists where they lived in territorially defensible numbers, immediate political risk to the state subsided. Voluntary disengagement all-but eliminated British interest in Ireland. The novel device of devolving all power over domestic policy to the local majority in Northern Ireland confined the contest of nationality which had defined British-Irish relations since the 1840s into the new 'province'.

While the Irish Free State was territorially truncated, the new state was born without significant internal minority resistance. Partition ensured that the national struggle was elsewhere, confined overwhelmingly within the new Northern Ireland. As the remnant protestant community was slowly assimilated, anti-Britishness became a constitutional obligation rather than an immediate priority.

More gradually, the evident inability of independent Ireland to change the partition settlement limited the fascination of the 'unredeemed' fourth green field. In Girardian terms, Northern Ireland's distinct territorial identity and the inability of Ireland to effect change through violence reduced, but could not eliminate, the level of external mimetic rivalry over the contested territory. The 'rest of Britain' and, eventually, 'the rest of Ireland' 'externalised' and slowly moderated their own historic hostility.

But the national dispute was not so much resolved as 'contained' and concentrated into Northern Ireland. Neither integrated into the imperial homeland nor an independent nation state, Northern Ireland became, in Wright's description, an institutionalised 'ethnic frontier'.

Historically 'a place between', the north of Ireland was now 'a place apart' in a permanent 'state of exception'. Territorial legitimacy, presumed elsewhere in Britain and Ireland, was endemically at risk. Rival claims to sovereignty and legitimacy defined the single axis of division between vigilant 'supporters' and actively hostile 'rejectionists' of the new arrangements.

Unionist attempts to assert the monopoly of violence by the state could not be separated from their endemic insecurity. Security depended on maintaining the fragile balance of forces. Elections measured the balance with no expectation of change. With a Unionist monopoly on power, Nationalist hostility to the state shaded into sympathy for resistance, while Unionists developed the legal framework for permanent emergency law despite their parliamentary monopoly. In this, Northern Ireland almost exactly matched Dumouchel's description:

"It is important to remember that the reign of suspicion is the contrary to the rule of law... Foes are rendered inoffensive, incapable of doing harm, before they are able to act. The object is not justice, which seeks to maintain a degree of proportion between the crime and the punishment, but efficiency at the cost of a few 'unfortunate mistakes'... Suspicion is to law what a pre-emptive strike is to a declaration of war." 17

The cycle of antagonism ultimately impinged on every relationship, embedded in politics, residence, employment practices, policing, education, arts and sport and local government. Almost none of this was officially acknowledged. Yet, for as long as actual 
violence remained suppressed, the state presented itself as uncontested. Only the permanent existence of emergency legislation told otherwise.

\section{FROM CONTAINMENT TO ESCALATION TO CONTAINMENT?}

Northern Ireland's political balance collapsed in the late 1960s. In Western Europe, the alliance against communism and political co-operation had established an unexpected degree of territorial stability. After 1945, Britain exited Empire almost by stealth, presenting decline as a new-found commitment to 'self-determination', albeit on the random boundaries of imperial conquest. Ominously, decolonisation was most violent where the descendants of imperial settlements violently resisted a future as resented minorities, such as Southern Africa and French Algeria. Here, settlers found themselves repudiated as uniquely racist dinosaurs. The western powers presented liberal democracy as progressive inevitability, as natural now as it had been precarious in the 1930s.

Meanwhile, Ireland and Britain reached an unspoken modus vivendi. Both states formally restated their claims to sovereignty Northern Ireland in the 1940s but both were increasingly focussed on joining the European Economic Community. Neither showed any sign of wishing to wake the sleeping dog.

The speed of escalation in violence in Northern Ireland demonstrated that it was not only the dog that was asleep. When demands for full civil rights and an end to discrimination against Catholics met significant Unionist opposition in the late 1960s, violence erupted on an unprecedented scale, it appeared to catch Dublin and London unprepared. Rioting escalated into confrontation between the police and civil rights protesters and inter-community violence. The crisis of the 1920 s was evoked in the reappearance of groups claiming a historic legitimacy for violence.

As violence escalated at an alarming rate, the underpinning crisis of legitimacy was re-exposed. Both governments found themselves rapidly drawn back into the crisis. With British acquiescence, the Northern Ireland government activated the emergency powers legislation and introduced internment without trial. But instead of restoring order, the legitimacy of the state in Northern Ireland now faced international scrutiny. Inexorably, the British state was being drawn into direct confrontation with Irish Nationalism. Within six months, the British army was being internationally condemned for shooting civilians on the street. Meanwhile, members of the Irish government were sacked for allegedly arranging for arms to be smuggled into Northern Ireland. The Irish government pleaded with UN to send peacekeepers.

But given that Northern Irish politics was conducted as mortal combat over belonging to Ireland or Britain, the most striking aspect of Northern Ireland is its survival as a separate political entity. The isolation of the political priorities of Northern Ireland by partition/devolution had decisively weakened national solidarity. To an exceptional extent, violence in Northern Ireland failed to rouse the majority of the population in either Britain or Ireland to action. The British press explained the conflict not in historic British-Irish terms, but as an incomprehensible 'religious war' between remnant 'Catholics and Protestants'. 
Meanwhile despite the explicit constitutional claim to sovereignty over the whole of Ireland, the crisis in the North merely emphasised the inability of the Irish state to do anything practical about the border. In practice both governments acted to limit themselves against the risk of being drawn into a national conflict which their voters now regarded as 'little to do with us.'

Containing violence became the key priority. The need to avoid being drawn into deeper antagonism meant controlling the response of the state, forcing the British State to intervene directly. In March 1972, to Unionist fury, Northern Ireland's devolved parliament was summarily abolished as 'a temporary measure'. At the same time, both Governments made very clear that they regarded this as temporary. Northern Ireland's distinct arm's length special status was explicitly retained. The Irish government introduced its own draconian measures to isolate anyone advocating violence south of the border. The governments actively co-operated in a desperate attempt to negotiate voluntary power-sharing deal for Northern Ireland in 1973.

But when the experiment in power-sharing collapsed after 5 months in the face of mass protests by Unionists, the British government was left to administer Northern Ireland alone. Republican demands for British withdrawal and Unionist proposals to restore the principle of majority-rule were rejected, but power-sharing remained impossible. Instead, the British government pursued 'the acceptable level of violence' and a 'normalisation' of law and order through a combination of massive army presence, commitments to address inequality and physical separation 'peace walls'. Superior military force gradually restricted violence into segregated, often poor, urban areas where paramilitary organisations had active support and rural districts with continuous traditions of struggles for land and power in a long, grinding 'war of attrition'. Meanwhile, England, Scotland and Wales were protected from Northern Ireland by means of the Prevention of Terrorism Act.

\section{THE PROCESS OF PEACE?}

Overwhelming force could protect minimum order, but not create legitimacy. When the British government withdrew the special status granted to prisoners arrested for political and terror offences, republican prisoners starved themselves to death in defiance of the attempt to "label our liberation struggle as criminal" ${ }^{18}$. The 'martyrdom' of the hunger strikes polarised the population, rejuvenated Irish republicanism and underlined both the sacred intensity of the demand for Irish self-determination and the limits of the law's ability to assert a monopoly of legitimate violence.

In 1982, Britain was galvanised by the 'humiliation' of the Argentinian invasion of the Falkland Islands into a frenzy of national outrage. Yet in the face of apparently endless violence at the same time, Northern Ireland was, more than ever, distanced as 'other'. Territorial ambition was reduced to historic obligation, and 'containing' the crisis in Northern Ireland.

The prospects for British disengagement or ending hostilities seemed ever-more distant. In an atmosphere approaching despair, both governments edged towards cooperation. The Anglo-Irish Agreement that emerged in 1985 proved to be the most 
radical recalibration of inter-governmental relationships in Ireland since 1920. Without repudiating historic commitments, the governments framed their desire to contain and manage violence within an ill-defined, commitment, to 'reconciliation'. Peace in Northern Ireland could not be won by asserting one nationality over the other, but by renouncing violence. Implicitly, and in contrast to official constitutional theory, both governments were edging towards a supranational transcendence that drew an international antithesis between the rule of law informed by international norms and all other violence, terror or antagonism. By placing the de-nationalised 'victims of violence' at the centre, violence in pursuit of national self-determination was abandoned. Patriotism now implied accommodation with, rather than the destruction of, the national enemy.

The consequences were not immediately clear, or even intended by the signatories. Joint sovereignty had been explicitly ruled out. However, the UK government conceded a special role to Ireland for safeguarding equality of treatment and raising security concerns in Northern Ireland, established a joint British-Irish secretariat to liaise between the governments and regular meetings over Northern Ireland between the British Secretary of State and the Irish Foreign Minister in exchange for security co-operation and a restatement of the position that Irish unity would not take place without the consent of the majority in Northern Ireland. Underpinning this, the Agreement established a new 'International Fund for Ireland' (IFI) to invest in economic regeneration and reconciliation across the island of Ireland, financed by donations from the United States, the Commonwealth and the European Union.

In Northern Ireland, reaction to the abandonment of national solidarity was immediate and dramatic. Enraged Unionists demonstrated and agitated in a total mobilisation against the new deal. Republicans reacted with horror against the 'nationalist nightmare'. Imported arms and munitions from the eastern bloc, Libya and South Africa kept the street war alive and there was no immediate decrease in the level of murderous violence. Both were alive with accusations of betrayal and abandonment. But despite continuing atrocity, no party could create significant external political momentum against the Agreement. Critically, the key axis of negotiation was with the Anglo-Irish framework, not between the Northern Irish antagonists.

Reconciliation was in effect a new transcendence in British-Irish affairs and a political framework which governments applied strictly to Northern Ireland. The fact that the British and Irish states set limits to their willingness to uphold self-determination in Northern Ireland was a product of Northern Ireland's 'otherness'. Although the policy was ostensibly focussed on building relationships between Northern Ireland's warring factions, it had to be pursued against all of their instincts.

The moderation of nationalism by reconciliation was a remarkable political development. Northern Ireland's isolation from the mainstream of British and Irish politics ensured that decades of mimetic violence over the territorial sovereignty and the monopoly of violence did not galvanise Britain and Ireland into war. Instead, in the face of years of attempting to pacify and manage, the overwhelming lesson was the hopelessness of violence. In addressing violence, reconciliation was not an admission of national defeat but the last best hope of preventing the escalation to the extremes. Furthermore, in the context of post-war liberal democracy, by establishing an international ethical framework it modified the imperative of national self-determination and 
created the inter-national context within which a territorial monopoly of violence could be exercised.

In real political terms, nationalists of every sort were now confronted by the overwhelming combined forces of the nations they purported to defend. Paradoxically, the only question was the extent to which 'reconciliation' would have to be externally 'enforced' or whether it could be adopted by negotiation. For the governments, the primary goal was the devolution of responsibility for reconciliation to the parties in Northern Ireland, ensuring that its volatile antagonism was contained. For the local protagonists, engagement in the peace process was primarily necessary to limit further abandonment, only possible by substituting their own agreement for those between governments.

It was clear to everyone that this would require facing into a future where antagonists shared power on the basis of equality. Much more problematically, however, it also implied that violence in pursuit of 'our' cause would be regarded as equivalent to violence pursued by 'our enemies', an acknowledgement that no party, including governments, was willing to make.

Over twelve years, in a multidimensional series of negotiations collectively known as the 'peace process', governments and parties tiptoed into fundamental negotiations. Communication was re-established with Unionists by the late 1980s. By 1994, the key paramilitary antagonists agreed to ceasefires. American diplomacy and European finance increased the room for manoeuvre and widened community momentum for change beyond political parties. Despite a boycott by radical Unionism around Ian Paisley's Democratic Unionists (DUP), the governments established talks in1997 that concluded with the Belfast or Good Friday Agreement (GFA) in April 1998.

\section{BETWEEN RIVALRY AND RECONCILIATION}

The political centrepiece of efforts to establish the transcendence for reconciliation was the Good Friday Agreement. This was established unambiguously in the second paragraph of the text:

"The tragedies of the past have left a deep and profoundly regrettable legacy of suffering. We must never forget those who have died or been injured, and their families. But we can best honour them through a fresh start, in which we firmly dedicate ourselves to the achievement of reconciliation, tolerance, and mutual trust, and to the protection and vindication of the human rights of all."19

Taken literally this amounts to the renunciation of one relationship for another by all signatories, including, those from Northern Ireland. Furthermore, all parties explicitly affirmed their "absolute and total commitment to exclusively democratic and peaceful means of resolving differences on political issues" 20 and accepted that it was "essential to acknowledge and address the suffering of the victims of violence as a necessary element of reconciliation."

Reconciliation and non-violence was underpinned by an emphasis on international human rights law (which no law can infringe) and statutory equality. Most 
dramatically of all, the Good Friday Agreement severed the link between territorial sovereignty and unique citizenship, reconfiguring national identity as a matter of choice between equals rather than sacred obligation:

"the birthright of all the people of Northern Ireland to identify themselves and be accepted as Irish or British, or both, as they may so choose, and accordingly confirm that their right to hold both British and Irish citizenship is accepted by both Governments and would not be affected by any future change in the status of Northern Ireland."21

But if political responsibility was to be devolved, there was no way to avoid doing a deal with antagonism. Yet by setting 'reconciliation' against traditional national goals, it was turned into the measure of defeat for Northern Ireland's recalcitrant antagonists. If reconciliation was concession, protecting communal antagonism was a success. The consequences of this have proved profound.

The political deal which emerged in 1998 was a complex hybrid. The signatories reaffirmed the formal sovereignty of Irish self-determination while accepting that a united Ireland could only be achieved "with and subject to the agreement and consent of a majority of the people of Northern Ireland." 22 Power-sharing in Northern Ireland was made mandatory, North-South co-operation on identified issues was institutionalized and a new British-Irish Council was established to bring together the various elected institutions of 'the islands' in a largely consultative forum. Equality of opportunity was to be enhanced and regulated through an Equality Commission and public life was to be pursued within a framework of 'parity of esteem' between nationalism and unionism.

But within Northern Ireland, the structures were strictly consociational. Ministerial posts were assigned proportionally to party strength creating a coalition emphasizing participation by right. MLAs designated as Unionist, Nationalist or 'other', because a number of votes required 'parallel consent'. Groups of 30 MLAs could raise 'petitions of concern' vetoing measures without cross-community consent.

More significantly, the negotiators relied on ambiguity to close the deal on a number of critical issues. The most incendiary related to "violence connected to the affairs of Northern Ireland', including the release of prisoners, disclosure of state activity, the vindication of victims and the disbanding and disarmament of paramilitary organisations. Thus prisoners were released before the end of their sentences, but without amnesty. Governments signed up to human rights but without specific commitments to truth-telling. Victims were acknowledged with only vague further promises and disarmament depended on voluntary action by groups who were only indirectly represented at the talks. In contrast, the need for policing reform was recognised, and handed over to an Independent Commission on Policing, which reported in $1999,{ }^{23}$ leaving it to be imposed by the international coalition despite inevitable Unionist and republican objection.

The controlling dynamic of Northern Ireland since 1998 became the interaction between the recognition of the impossibility of violence and the unresolved logic of mimetic national antagonism. 


\section{TRUCE OR TRANSFORMATION?}

In 1985 Britain and Ireland concluded that the decisive challenges in Northern Ireland were violence and the escalation of conflict. Legitimacy and the rule of law depended on the transcendence of inter-national solidarity against killing over national self-determination. By placing the renunciation of violence over the claims of national egotism they made one of the most innovative interventions in international relations since 1918, and incurred the hostility of most of the direct political antagonists in Northern Ireland itself.

The symbolism of Good Friday seemed to reinforce the connection between the crucifixion and the strategic emphasis on the victims of violence. Although supported by $70 \%$ in the referendum in Northern Ireland, the residual dynamics of reciprocal antagonism almost destroyed the Agreement over the next five years. Ambiguity in the rules of disarmament unravelled making it impossible for pro-Agreement Unionists to commit to devolved government without risking electoral annihilation. Failure to secure devolved government prevented moderate Nationalists advocating unambiguously for disarmament. Community relations were seriously strained when loyalist protesters in North Belfast attacked children and parents on their way to a Catholic Primary school. In 2002, the crisis of trust over disarmament escalated to the point that devolved government collapsed and the British governments re-instituted direct rule. Elections in 2003 destroyed the political base of the parties at the core of the Good Friday Agreement to the benefit of the political party most closely identified with unbending hostility.

In effect, antagonism in Northern Ireland forced the government to resume responsibility for reconciliation. The political compromise implementing 'reconciliation' of trading devolved responsibility for managed antagonism had fallen apart. The governments and the international community had no alternative but to continue, but they did so increasingly reluctantly. Westminster passed legislation to implement Patten's policing reforms (supported enthusiastically by the Irish and US governments, the Catholic Church and the Gaelic Athletic Association but accepted with great reluctance by the Unionist parties in Northern Ireland and rejected by Sinn Fein) and introduced a comprehensive strategy for community relations and reforms to equality law without local political support. Meanwhile, huge European and US financial support maintained popular participation in 'reconciliation.'

But increasingly the governments were only interested in establishing devolved government. In practice, this meant both defining reconciliation as devolution and renegotiating reconciliation with parties that were historically more committed to exclusive versions of national legitimacy to achieve devolution. Ambivalence around decommissioning was resolved especially when US objection to IRA killings and a bank robbery forced a process of visible decommissioning. To entice the parties, the governments unilaterally recast aspects of the Agreement at St Andrews to reduce the level of integrated leadership and reinforce communal separation of the devolved Assembly, ${ }^{24}$ but other aspects of reconciliation and the Agreement, such as commitment to integrated education, inter-community relations or developing equality, establishing a civic forum or bill of rights were essentially set aside, and with them any necessary evolution away from national separation. 
The dramatic reward was agreement by both Sinn Fein and DUP to enter a historic pact to govern Northern Ireland in 2007, greeted with genuine surprise across the world. Devolution instantly removed the UK government from direct political responsibility for most of Northern Ireland's internal affairs, with the exception of reserved matters and the still contentious issue of policing and justice. The meaning of reconciliation in practice now depended on the extent to which the new political relationship could contain or transform the underlying rivalry.

\section{AFTER RECONCILIATION: TRUCE AND TRANSFORMATION IN NORTHERN IRELAND SINCE 2007}

In effect, the British and Irish governments made clear that the heavy lifting in relation to establishing a territorially viable state, including the monopoly of the legitimacy, was completed by devolution in 2007. A number of obvious things remained to be achieved - including the devolution of policing and justice - but the intergovernmental doctrine was now that the remaining decisions about towards reconciliation should be taken in Northern Ireland.

In the years that followed, the transformation of relationships between Britain and Ireland was formally underlined. The state visit of Queen Elizabeth II to Ireland in May 2011was hailed as a 'spectacular diplomatic triumph' ${ }^{25}$ (Daily Telegraph, 2011) Likewise the reciprocal state visit of President Higgins to Britain in April 2014 was described as a cultural 'catharsis'. ${ }^{26}$

The new Northern Ireland administration initially sought to focus on issues of common interest - primarily economic - rather than resolving contentious issues. But as the global financial crisis rendered hopes of an economic dividend implausible, so the evidence of unresolved antagonism re-surfaced.

As a variety of triggers escalated into more general disputes about the balance of power, the Executive repeatedly polarised and looked for external support. Agreeing arrangements for policing and justice required the direct re-intervention of the British, Irish and US governments in 2010. The final deal managed the unique challenges of administering common justice in a society characterised by hostile suspicion by removing the new Ministry from the consociational proportionality arrangements, allocating it uniquely to a Minister with cross-community support. In 2012, serious rioting broke out when Belfast City Council reduced the number of days the union flag was flown on City Hall. In 2013, disputes over single parade routes, escalated into confrontation. When an internal dispute among republicans spilled into assassinations in 2015, Unionists called time on normal political business.

Despite a marked reduction in the level of overt violence, paramilitary activity continued and police and prison officers lived under a continuing death threat. Meanwhile, the Executive made slow progress on removing the so-called peacelines or reducing residential segregation and seemed to step back from integrated education. Attempts to extend equality or promote a Bill of Rights fell on the rock of intercommunity division while promises to devise a policy to improve community relations took six years to materialise, driven in the end by the need to demonstrate to an international audience at the G8, that Northern Ireland was indeed making progress. 
Yet against this, shared government followed a distinct pattern of survival. Disputes between the rival groups in Northern Ireland escalated until the point that only external mediation could break the impasse, at which point the reluctant governments accepted the need to intervene. Talks also took on an identifiable arc as all parties appeared to wait until the last possible moment to make decisions, conceding only when it was clear that the alternative was a total collapse in the system. Clearly, escalating rivalry towards violence in Northern Ireland remained a risk, yet all parties appeared to accept that only shared government and non-violence could provide any way forward. More problematically, however, the parties appeared to have made little progress at making concessions to one another on issues of antagonism and continued to rely on the mediation and resources of governments.

\section{TERRITORIALITY, POLITICS AND VIOLENCE IN NORTHERN IRELAND}

For Rene Girard, human efforts to contain violence have reached a critical juncture. Drawing on von Clausewitz's dictum that war has 'the form of a dual' and a tendency to escalate to the extremes. ${ }^{27}$ Girard rejects Hegel's optimism that dialectical conflict leads to universal Aufhebung. Because violence cannot be checked by superior violence, violence has an unprecedented capacity to escalate rapidly to the extremes. "Violence can no longer be checked. From this point of view we can say that the apocalypse has begun... In a more realistic manner than Hegel, Clausewitz showed the utter powerlessness of politics against the escalation to extremes. Ideological wars, monstrous justifications of violence, have led humanity to the stage beyond war where we are today." 28

Since 1918, the dynamic of national self-determination, especially in territories where no single nation can prevail without violence, illustrates the modern dilemma. The collapse of the imperial in the face of a politics of liberty, becomes enmeshed in mimetic rivalry over territorial control, rendering the whole notion of territory, as a cornerstone of global order increasingly unable to manage violence. Instead of the monopoly of legitimate violence, every rival claims legitimacy for their violence. Where a balance of forces cannot be established or the intervention of outside powers transforms local ethnic violence into international conflict, the result is potential lethal for international affairs.

The question of whether politics has any response to this challenge is therefore urgent. In this regard, the emergence in Northern Ireland of 'reconciliation' as a framework for international ethical norms beyond national self-determination was especially significant. The prioritisation of an obligation to victims over the demands of national ascendancy represents a potentially important illustration of the capacity to arrest the escalation to the extremes through the renunciation of violence.

At the same time, it is evident that the gap between reconciliation and mimetic rivalry remains unclosed. In many ways, the commitment of the British and Irish governments to reconciliation in Northern Ireland can be attributed to their relative indifference to the outcome and their unusual distance from its polarised mimetic dynamics. As a consequence, the British and Irish governments were not confronted with the need to renounce their own position, but called on a smaller 'other', in this case Northern Ireland to do so. In spite of the huge amount of money spent on resolving 
conflict, however, the outcome has been ambivalent. On the one hand, the antagonism of Northern Ireland has clearly entered a new less violent chapter. At the same time, it has proved impossible to simple renounce the impulse to mimetic escalation or hostility.

The challenges to reconciliation in the future proved to be most acute in relation to violence in the past. In its focus on a new start, the Good Friday Agreement left untouched whether violence on behalf of self-determination prior to 1998 was or was not legitimate.

Violence in Northern Ireland's deep-rooted ecosystem of antagonism escaped simple definitions of crime and war, leaving a legacy of widespread ambivalence about violence, unacknowledged complicity, contested categories of heroism and criminality and contrasting experiences of the rule of law. Both the Good Friday Agreement and the Patten Commission eschewed any formal reckoning with history, in favour of a 'New Beginning'. Both elevated the memorability of "innocent victims of violence", but left hanging the reciprocal Girardian movement of the revelation of complicity.

But it quickly became apparent that drawing a line was impossible in the face of the social and cultural legacy of violence and the demands of international human rights law. It was equally clear that justice administered through normal legal processes would be both contested and increasingly difficult as time passed. Above all, political parties were wedded to particular narratives of crime and heroism which could be undermined by certain processes and vindicated by others. Despite an early release programme, victims support schemes, inquiries, coronial inquests, ombudsman investigations and a full-scale Commission ${ }^{29}$ nobody was willing to expose their complicity with violence at the cost of losing control of the moral economy. What remained was a culture of accusation and counter-accusation and exposure by journalistic investigation. The price of ending mimetic rivalry that nobody seemed willing to face remained the question of acknowledging participation in violence and taking responsibility for restoring relationships.

'Reconciliation' has made an important contribution to the search for a new politics of legitimacy in a divided society. Yet until now the mimetic fragility of relationships in Northern Ireland was reinforced by the growing confidence of relationships between London and Dublin. It remains to be seen whether reconciliation between Britain and Ireland will survive Brexit. The Northern Ireland peace project remains a work in progress. Girard's challenge to politics remains unresolved.

\section{NOTES}

${ }^{1}$ Max Weber, "Politik als Beruf," in Max Weber, Gesammelte Politische Schriften (Munich: Duncker \& Humboldt, 1924), 396-450.

${ }^{2}$ Giorgio Agamben, State of Exception (Chicago: University of Chicago Press, 2005), 23.

${ }^{3}$ Hannah Arendt, The Origins of Totalitarianism (New York: Schocken Books, 1951), 231.

${ }^{4}$ Rudyard Kipling, "The White Man's Burden," in Rudyard Kipling, Complete Poems (London: Wordsworth, 2001), 334. 
${ }^{5}$ See Transcript of Woodrow Wilson's Fourteen Points (1918), https://www.ourdocuments.gov/doc.php?doc=62\&page=transcript (accessed 12

September 2016)

${ }^{6}$ Margaret MacMillan, Peacemakers (London: John Murray, 2001).

${ }^{7}$ Frank Wright, Northern Ireland: A Comparative Analysis (Dublin and London: Gill and MacMillan, 1987), 1-11.

${ }^{8}$ Ibid, Wright, "Northern Ireland", 11-50.

${ }^{9}$ Gordon Lucy, The Ulster Covenant: A Pictorial History of the 1912 Home Rule Crisis (Newtownards (Northern Ireland): Ulster Society/Colourpoint, 2012), 1.

${ }^{10}$ Timothy Snyder, Bloodlands: Europe Between Hitler and Stalin (London: Vintage, 1910).

${ }^{11}$ Rene Girard, Violence and the Sacred (Baltimore(MD): Johns Hopkins University Press, 1977).

${ }^{12}$ Ibid, Girard, "Violence and the Sacred', 271.

${ }^{13}$ Rene Girard, Things Hidden Since the Foundation of the World (London: The Athlone Press, 1987), 180-223.

${ }^{14}$ Paul Dumouchel, The Barren Sacrifice (East Lansing, MI: Michigan State University Press, 2015), xxxii.

15 Ibid., 166.

${ }^{16}$ Wright, "Northern Ireland", 220.

${ }^{17}$ Dumouchel, "The Barren Sacrifice", 167.

18 Bobby Sands, Writings from Prison (Cork: Mercier Press, 1983), 225.

${ }^{19}$ See Belfast Agreement (1998), paragraph 2, https://www.dfa.ie/media/dfa/alldfawebsitemedia/ourrolesandpolicies/northernireland/go od-friday-agreement.pdf (accessed 16 November 2016)

${ }^{20}$ Ibid, paragraph 4.

${ }^{21}$ Ibid, Constitutional Issues, 1(vi).

${ }^{22}$ Ibid, Article 1 (ii).

${ }^{23}$ Independent Commission on Policing for Northern Ireland, A New Beginning; Policing in Northern Ireland (London and Belfast: HMSO, 1999).

${ }^{24}$ See St Andrews Agreement (2006), https://www.gov.uk/government/uploads/system/uploads/attachment data/file/136651/st andrews agreement-2.pdf, accessed 15 November 2016.

25 "The Queen in Ireland: Standing ovation in Dublin," Daily Telegraph, 20 May 2011.

26 "The Irish state visit was a piece of public theatre, but also a catharsis," The Guardian, 11 April 2014.

${ }^{27}$ Carl von Clausewitz, On War (Princeton: Princeton University Press, 1976), 75.

${ }^{28}$ Rene Girard, Battling to the End (East Lansing MI: Michigan State University Press, 2010), 209-10.

${ }^{29}$ See Robin Eames and Denis Bradley, Report of the Consultative Group on the Past (2009), http://cain.ulst.ac.uk/victims/docs/consultative_group/cgp_230109 report.pdf accessed 9 October 2016.

Duncan Morrow is lecturer in Politics at Ulster University, where he is also Director of Community Engagement. Previously, he was CEO of the Northern Ireland 
Community Relations Council where he championed the concept of a shared future and peace-building through community practice, public policy, research and active learning. 